Under both the above terms are comprised a large number of trifling injuries. Very seldom any of a serious character are met with.

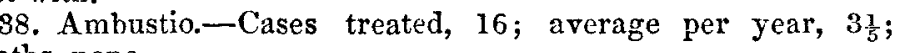
deaths, none.

These were scalds and superficial burns, which happen sometimes during ball-firing.

$$
\text { (To be concluded in our next.) }
$$

\section{ILLUSTRATIONS OF DIFFICULT PARTURITION.}

Bx J. HALL DAVIS, M.D. Lond., L.R.C.P. PHYSICIAN TO THE ROYAL MATERNITY CHARITY, AND TO TKE SAINT PANCRAS INFTRAIARY.

(Continued from p. 5.)

An arm-presentation labour, with prolapse of the funis. Turning attempted one hour after the discharge of the liquor amnii, as also at a later period, unsuccessfully; Delivery by perforation of the chest, \&c. Convalescence good.

December 5th, 1850, at half-past ten, P.M., I was requested by the surgeon in attendance to come to his assistance, in a case of difficult labour. E. N-, aged thirty-two. Seventh child. Previous labours had been easy. The membranes had given way after two strong pains, at half-past six P.M., discharging a large quantity of liquor amnii; the pains continued severe for half an hour, when they ceased. A midwife in attendance sent for $\mathrm{my}$ friend at half-past seren, who finding the arm and funis presenting, tried to turn, but without success, although he managed to bring a foot to the pelvic brim; he was alike unsuccessful on repeating his attempt to turn, when the patient had been placed under the influence of a full dose of opinm.

At my visit, at half-past ten, I found an arm and foot at the brim of the pelvis, with coils of the funis without pulsation; the patient not feverish nor plethoric. Thinking that there might yet be a remote chance of saving the child, the cord having only recently ceased to pulsate, and finding turning impracticable at present, I administered chloroform as far as I deemed it judicious to venture, one ounce of the fluid being disposed of, but without the desired effect of relaxing the rigidly contracted uteras. I may say that the specimen of that medicine, judging from its effects upon myself, seemed to be good. I now perforated the axilla, my friend, at my request, keeping the presenting arm on the stretch; I removed the viscera of the thorax through the opening thus made, and by a puncture with my finger and a crotchet, gradually brought the child through the brim, pelvic cavity, and outlet. The pelvis appeared to me deeper than a standard pelvis, which made the axilla less accessible than otherwise it would have been, and rendered the operation a little more difficult. The placenta was quickly thrown off into the vagina, and thence removed within ten minutes after the birth of the child. The child was of average side; full term. The pulse after delivery was 90 , of moderate strength. The uterus was left favourably contracted. The patient's puerperium was passed through without a single had symptom.

Remarks.-Had my friend been called to this patient before, or immediately after the discharge of the waters, in all probability his attempts to turn would have been successful, and the child's life would have been saved. Of the three remedies for the subduction of inordinate uterine action-bleeding, opium, chloroform-the first was contra-indicated by the patient's freedom from pyrexia and plethora, her condition rather below than above par; the second and third sedatives were tried, but without responding in any degree to our wishes. The only resource left for the relief and security of the patient, was delivery by embryotomy, after the manner indicated for a transverse presentation. In the instances of labours with large children presenting transversely, it is, as I have already illustrated, necessary to decapitate before we can succeed in extraction, but the average dimensions of the child in this instance rendered unnecessary that part of the operation.

Another arm-presentation labour, with funis prolapsing, and partial placenta provia, attended by much flooding during a part of the labour; a third labour; previous labours protracted, and children still-born: patient's age twenty-eight; deformity by rickets. Opium failed as a sedative of spasmodic action; chloroform succeeded, and rendered turning practicable.

Feb. 12th, 1850.-Nine P.M.: I was requested to risit, in a parochial infirmary, a poor woman, deformed by rickets, of short stature and spare habit, aged twenty-eight, in labour of her third child, at full term. I was informed that her previous labours had been protracted, and terminated by still-births. The membranes had broken at midday; there had been much hæmorrhage, which, on examination, appeared to have been determined by a partial presentation of the placenta. Attempts at version bad been made, on two different cccasions, without success, even after the patient had been subjected to the influence of a full dose of opium.

My attempts were alike fruitless, until I had placed the patient under the influence of chloroform, of which six drachms were disposed of, in separate portions, upon a handkerchief, loosely held over the nostrils and mouth. The child was then turned with perfect ease. In performing the operation, I employed the tape-noose to fix the foot at the brim, while with the fingers of the other hand I pressed up the presenting part. The patient was very restless and unmanageable before the exhibition of chloroform ; calm afterwards, and during a part of the time that w: $s$ devoted to the operation, unconscious. The child was stillborn, as was to be feared after so long delay and pressure on its circulation. The after-birth followed in less than ten minutes, witbout hæmorrhage. No inconvenience followed the use of the chloroform, beyond vomiting three or four times, what had been previously taken. The patient was left with a well-contracted uterus, and a good pulse.

Remarks.-An earlier resort to the exhibition of chloroform would, in all probability, besides shortening the patient's suspense and suffering, have saved the child's life. Abstaining, as I do, from chloroform from choice, in natural labour, I deem a case of this kind, in the absence of any organic disease or peculiarity to contraindicate its exhibition, admirably adapted for its employment. That agent, it was seen, succeeded in diminishing the spasmodic action of the uterus, opposing the efforts to turn, where a corresponding quantity of opium had entirely failed. In one of my former illustrations, I related a case of placenta prævia, in which I had been consulted, attended by much hæmorrhage, where the uterine spasm was so great that turning was quite impracticable. Opium was inadmissible on account of a peculiarity of the patient's constitution, in reference to that drug. Chloroform was administered at my suggestion to the production of its sedative effect : the operation of turning then became easy, and was completed in time to save the child, which was living and vigorous on the following day, and for aught $I$ know to the contrary, is so at the present time. I have not, in the few cases, nineteen in number, in which I have given this agent, observed any increased tendency to hæmorrhage from its use. I have not found it in that experience to diminish strictly parturient action. It has appeared to me that its sedative effects on the uterus have been limited to the subduction of irregular or spasmodic action of the muscular fibres of that organ, which, I take it, is the kind of resistance opposed to our manual proceedings in cases of difficult or impracticable turning.

Russell-place, 1852.

\section{A firror}

OF THE PRACTICE OF

\section{MEDICINE AND SURGERY IN THE}

\section{HOSPITALS OF LONDON.}

Nulia est alia pro certo noscendi via, nisi quam plurimas et morborum, et dissectionum historias, tum aliorum proprias, collectas habere et inter se comparare.-Morgagni. De Sed. et Caus. Jlorb., lib, 14. Procmium.

\section{KING'S COLLEGE HOSPITAL. \\ Cases of Cleft Palate; Staphyloraphy; Perfect Union.}

(Under the care of Mr. Fergusson.)

IT will be readily understood by all those practitioners who are acquainted with the various papers which have from time to time appeared upon improved methods of staphyloraphy from the pen of Mr. Fergusson, that we watch his operations for cleft palate with peculiar interest. Indeed it happened last summer that, by a strange coincidence, one of these operations assumed a more than usually important character, as M. Séd:llot, the professor of surgery at Strasburg, and Mr. Avery, were present. Our readers are aware that both these gentlemen have laboured very successfully in the subdivision of operative surgery which we are this day considering. Some misapprehension at one time existed as to the relative 